FACTA UNIVERSITATIS

Series: Physical Education and Sport, Vol. 18, No 1, 2020, pp. 207 - 218

https://doi.org/10.22190/FUPES181220018N

Professional article

\title{
PROGRAMMING AND MANAGING METHODOLOGY OF EDUCATION TRAINING PROGRAMMES
}

\author{
UDC 796.015.1
}

\author{
Vesna Nemec $^{1}$, Predrag Nemec ${ }^{1}$, Saša Veličković $^{2}$, Miloš Milošević ${ }^{1}$ \\ ${ }^{1}$ Faculty of Physical Culture and Sports Management, Singidunum University, Belgrade, Serbia \\ ${ }^{2}$ Faculty of Sport and Physical Education, University of Niš, Niš, Serbia
}

\begin{abstract}
The main aim of this paper is to present theoretical knowledge and to answer the question of organizing, programming, conducting and managing the training process in order to achieve the best possible education training effects and to generate planned changes in the domain of the provided knowledge, abilities and skills of sportspeople. The findings have theoretical implications for methodological steps, programming algorithm, models and methods implemented in the process of programming and managing education training programmes and give an insight into the calculating, analysis, control and managing education training effects and changes. In accordance with the aim of the paper the multidimensionality of programming and managing methodology are highlighted. The presented methodological approach in designing education and training can be applied to all sports, however, not in its entirety, due to the specific methodological steps of some sports.
\end{abstract}

Key words: Algorithm, Programming Methodology, Training Effects, Training Changes

\section{INTRODUCTION}

Programming and managing education training programmes are based on the theory of a stationary, current and transition state or regimen, the development theory, the capacity theory, the theory of structural and functional ability, the adaptation and modification theory, the theory of effects, the theory of muscle force production, the theory of acquiring motor algorithms and programmes, the theory of motor learning, control and manipulation, the integral theory of movement and muscle force production (Momirović et al., 1987; Bonacin, 2004; Tomić \& Nemec, 2012; Milošević \& Milošević, 2013; Milošević \& Milošević, 2014; Milošević, Nemec, Životić, Milošević, Rajović,

Received December 20, 2018/ Accepted May 05, 2020

Corresponding author: Saša Veličković

Faculty of Sport and Physical Education, University of Niš, Čarnojevića 10a, 18000 Niš, Serbia

Phone: + $38118510900 \cdot$ E-mail: v.sale70@ gmail.com 
2014a; Milošević, Milošević, Nemec, Životic, \& Radjo, 2014b; Milošević, Džoljić, Milošević, Yourkesh, \& Behm, 2014c; Milošević et al., 2016; Nemec, Milošević, Nemec, \& Milošević, 2016; Milošević, Nemec, Nemec, \& Milošević, 2017).

Methodological concepts provide sportspeople (coaches, professors, athletes, etc.) with the knowledge regarding exactly what to do and why, as well as why not to, at all times, and what the outcome of the conducted training is (Milošević, Mudrić, Mudrić, \& Milošević, 2012).

The latest experimental research results, training theories and mathematical models in the field of education and training significantly accelerate learning processes, as well as the adaptation and transformation processes of athletes (Momirović et al., 1987; Bonacin, 2004; Milošević et al., 2012; Milošević \& Milošević, 2013; Milošević \& Milošević, 2014; Milošević et al., 2014a; Milošević et al., 2014b; Milošević et al., 2014c; Milošević et al., 2016; Nemec et al., 2016; Milošević et al., 2017; Milošević, Nemec, Nemec, \& Milošević, 2018).

Special attention is dedicated to the methods for data gathering and feedback analysis on the general output from education training effects and change managing systems (Momirović et al., 1987; Bonacin, 2004; Milošević et al., 2012; Milošević \& Milošević, 2013; Milošević \& Milošević 2014; Milošević et al., 2014a; Milošević et al., 2014b; Milošević et al., 2014c; Nemec et al., 2016; Milošević et al., 2016; Milošević et al., 2018).

Data acquisition and storing in specialized databases, and their complex structure analysis by stochastic and deterministic mathematical methods and procedures are quick and simple (Momirović et al., 1987; Bonacin, 2004; Milošević \& Milošević 2014).

Methodological concepts provide determining equations which depict various specific movements of athletes, force production, education training effects and changes in knowledge, force, aerobic and anaerobic capacities, the dynamics of an athlete's progress, their energy reserves and energy processes, the pace of their recovery while training and intermissions, the speed, time and level of supercompensation in various managing fields (Momirović et al., 1987; Bonacin, 2004; Milošević \& Milošević, 2013; Milošević \& Milošević 2014; Milošević et al., 2014a; Milošević et al., 2014b; Milošević et al., 2014c; Nemec et al., 2016; Milošević et al., 2016; Milošević et al., 2018). It provides a graphic presentation, print-outs of analysis results and reports, comparison of athletes, classes, and groups with the results of European and world athletes, and sequential search for the best possible training for an individual, class, group or sports team (Bonacin, 2004; Momirović et al., 1987; Milošević \& Milošević, 2014). Hence, it provides direct managing of education and training sessions, and managing and directing programmed current and cumulative training effects and changes (Momirović et al., 1987; Bonacin, 2004; Milošević \& Milošević, 2014).

The main aim of this paper is to present theoretical knowledge and to answer the question of organizing, programming, conducting and managing training process in order to achieve the best possible education training effects and to generate planned changes in the domain of the provided knowledge, abilities and skills of sportspeople. 


\section{THEORETICAL FRAMEWORK FOR PROGRAMMING AND MANAGING EDUCATION TRAINING PROGRAMMES}

\section{Semantic logical algorithm definition}

Step one: Defining the population: age, gender, sensitive zone data, health status, morphological status, the data on psychological status, the data on physical status, capacities and the level of technical and tactical skills of both individuals and the entire student or competing population (Tomić \& Nemec, 2012).

Step two: Defining variables for the assessment of athletes' abilities, their skills, advancement, energy and tactical requirements of fights - competitions, physical condition of sportspeople, aerobic, alactate and lactate education training, speed and force training, cognitive effects and changes. In addition, mechanic, myogenic, neurogenic, biochemical and physiological effects and changes in athletes' bodies (Milošević \& Milošević, 2013; Milošević \& Milošević, 2014; Milošević, et al., 2014a; Milošević, et al., 2014b; Milošević, et al., 2014c; Nemec, et al., 2016; Milošević, et al., 2016; Radenković, Bubanj, Berić, Stanković, Stojanović, Stojić. 2018; Stojanović, Radenković, Bubanj, Stanković, 2019).

Step three: Defining objects of management (educational objects, objects that define the fight - competition, then aerobic, anaerobic and energy status, status in speed and force, etc.) which are consequently changed under the influence of education and training (Momirović, et al., 1987; Bonacin, 2004; Milošević \& Milošević 2013; Milošević \& Milošević, 2014; Milošević et al., 2014a; Milošević et al., 2014b; Milošević et al., 2014c; Nemec et al., 2016; Milošević et al., 2016).

Step four: Defining tests (the programme and procedure for measuring metric units) for assessment of methods, education training, education training effects and changes (Momirović et al., 1987; Bonacin, 2004; Milošević \& Milošević, 2013; Milošević \& Milošević, 2014; Milošević et al., 2014a; Milošević et al., 2014b; Milošević et al., 2014c; Nemec et al., 2016; Milošević et al., 2016).

Step five: Defining operations for calculating values in set units (Momirović et al., 1987; Bonacin, 2004; Nemec et al., 2016).

Step six: Defining experiments for conducting diagnostics of the physical and education status and training status of an individual, group, team and specific age group (Momirović et al., 1987; Bonacin, 2004; Milošević \& Milošević, 2013; Milošević \& Milošević, 2014; Milošević et al., 2014a; Milošević et al., 2014b; Milošević et al., 2014c; Nemec et al., 2016; Milošević et al., 2016).

Step seven: Calculating the initial state and capacity (Momirović et al., 1987; Bonacin, 2004; Milošević \& Milošević, 2013; Milošević \& Milošević, 2014; Milošević et al., 2014a; Milošević, et al., 2014b; Milošević, et al., 2014c; Nemec et al., 2016; Milošević et al., 2016; Milošević et al., 2018).

Step eight: Calculating and evaluating dynamics of increase in observed variables of an individual, group and population according to the abilities of sportspeople and in accordance with the competition requirements (Momirović et al., 1987; Bonacin, 2004; Milošević \& Milošević, 2014; Milošević et al., 2018).

Step nine: Calculating the ideal final state of an individual, group (taxon), team and population in the observed variables (Momirović et al., 1987; Bonacin, 2004; Milošević \& Milošević, 2014; Milošević et al., 2018). 
Step ten: Differentiating between the initial, transition, and final state among individuals and groups in a team or school (Momirović et al., 1987; Bonacin, 2004; Milošević \& Milošević, 2014).

Step eleven: Defining material basis (conditions) where education training or education is performed: the number of playgrounds, gymnasiums, open and enclosed fields, gyms, equipment, the number of coaches, the amount of available finances, and competition calendar (Tomić \& Nemec, 2012).

Step twelve: Defining time structure of education training structure: the duration of specific training in minutes, the number of training sessions per day, the number of training sessions per week, the number of training sessions per month or year, the duration of a training session per day, week, month, year expressed in minutes, the transition of daily, weekly, and education training regimens; calculating time relation between physical and technical tactical preparation according to age and training; yearly, monthly, weekly and daily plans; defining periods without competitions, periods with one, two or more competitions per week, and the total number of competitions per year according to the age group (Momirović et al., 1987; Bonacin, 2004; Milošević \& Milošević 2013; Milošević \& Milošević 2014; Milošević et al., 2014a; Milošević et al., 2014b; Milošević et al., 2014c; Nemec et al., 2016; Milošević et al., 2016).

Step thirteen: Defining the set of classical and specific education training processes used by all age groups throughout perennial education training sessions (Momirović et al., 1987; Bonacin, 2004; Milošević \& Milošević, 2013; Milošević \& Milošević, 2014; Milošević et al., 2014a; Milošević et al., 2014b; Milošević et al., 2014c; Nemec et al., 2016; Milošević et al., 2016).

Step fourteen: Defining the set of education training methods which are used with all age groups during a perennial education training period (Momirović et al., 1987; Bonacin, 2004; Milošević \& Milošević, 2013; Milošević \& Milošević, 2014; Milošević et al., 2014a; Milošević et al., 2014b; Milošević et al., 2014c; Nemec et al., 2016; Milošević et al., 2016).

Step fifteen: Defining the voluntary influence of education and training: field (basic, targeted and advanced or situational training), the manner of influence (establishing, developing, managing, renewing), the training regimen (aerobic, anaerobic, etc.), the type of influence (all skills and abilities which are developed according to the given age groups) (Milošević \& Milošević, 2014).

Step sixteen: Data input on education training programmes: the ordinal number of one or more training sessions, date or dates of training sessions for which the programmes is designed, the athlete's name and surname or the name of the group (team - team 1 or team 2), the age of the athletes (Milošević \& Milošević, 2014).

Step seventeen: Defining (setting) training goals, that is, calculating current and cumulative education training effects for individual athletes for one or more training sessions in his/her field of expertise, aerobic, anaerobic, speed and force based on the diagnosed initial state, dynamics of athlete's advancement, the requirements of fights and material conditions (Momirović et al., 1987; Bonacin, 2004; Tomić \& Nemec, 2012; Milošević \& Milošević, 2013; Milošević \& Milošević, 2014; Milošević et al., 2014a; Milošević et al., 2014b; Milošević et al., 2014c; Nemec et al., 2016; Milošević et al., 2016).

Step eighteen (start programming individual training sessions): Defining goals and tasks for specific training session for the particular individual athlete, age group, group or team (Momirović et al., 1987; Bonacin, 2004; Tomić \& Nemec, 2012; Milošević \& Milošević 
2013; Milošević \& Milošević, 2014; Milošević et al., 2014a; Milošević et al., 2014b; Milošević et al., 2014c; Nemec et al., 2016; Milošević et al., 2016).

Step nineteen: Defining time structure of specific training session which corresponds to material conditions, age, skills level, current status and the dynamics of individual, team or group advancement which shall stimulate meeting the set goals (Momirović et al., 1987; Bonacin, 2004; Tomić \& Nemec, 2012; Milošević \& Milošević, 2013; Milošević \& Milošević, 2014; Milošević et al., 2014a; Milošević et al., 2014b; Milošević et al., 2014c; Nemec et al., 2016; Milošević et al., 2016).

Step twenty: Calculating the final state according to the exact time of education or training session, material conditions (equipment, halls, courts, finances, competition calendar, etc.), set goals, the initial state of age group for which the final states are being projected, and the rules for changing certain variables, that is, components of the athlete's state in relation to sensitive zones (Momirović et al., 1987; Bonacin, 2004; Milošević \& Milošević 2014).

Step twenty-one: Choosing a wider range of age-appropriate classical and specific training methods, with the corresponding level of skills and abilities of an individual or group, time structure, training period (periods without held competitions, periods with one or more competitions per week) and set goals for the particular training session (Milošević \& Milošević, 2013; Milošević \& Milošević, 2014; Milošević et al., 2014a; Milošević et al., 2014b; Milošević et al., 2014c; Nemec et al., 2016; Milošević et al., 2016).

Step twenty-two: Choosing a wider range of training methods according to the intensity of influence on skills and abilities of an individual or a group, as those which enable achieving set training goals for a particular training session at the moment of the training period (periods without held competitions, periods with one or more competitions per week) while using the chosen methods. Every presented method is described in accordance with the effects, the number of exercises and combinations of exercises, the number of repetitions of exercises or combinations, the duration of a single repetition, the amount and duration of intermissions, the duration of training sessions or the number of series, the speed of doing an exercise or combination, that is the regimen (Milošević \& Milošević, 2013; Milošević \& Milošević, 2014; Milošević et al., 2014a; Milošević et al., 2014b; Milošević et al., 2014c; Nemec, et al., 2016; Milošević et al., 2016).

Step twenty-three: Defining voluntary influence (effects and changes - advancement) of set training methods and models at the predefined time period of an athlete or a group of individuals. Then evaluating their influence and choosing a specific training session solely for those who match the set goals, programmed changes, the dynamics of acquiring skills and abilities of individuals in the defined time for training (Momirović et al., 1987; Bonacin, 2004).

Step twenty-four: Calculating capacity variables which an athlete is able to perform, calculate and evaluate the amount of individual training which is realised during particular training sessions (the information, force production, energy production, the speed of performance, the duration of performance, spatial perimeter of performance, the amount and frequency of performed training, the frequency and duration of intermissions, etc.) which generates programmed current or cumulative effects and changes (the advancement in skills, speed, the quantity of produced force, energy, lactic acid, oxygen debt, consumable oxygen, glycogen, phosphocreatine, the increase in force production, speed, energy, offense, defence, motion, recovery, decomposition and re-synthesis of energisers, etc.) for 
one or more training sessions (Momirović et al., 1987; Bonacin, 2004; Milošević \& Milošević, 2014; Nemec et al., 2016).

Step twenty-five (start evaluating): Quality control of education training programmes observer Graph 2 (Momirović et al., 1987; Bonacin, 2004; Milošević \& Milošević, 2014; Nemec et al., 2016).

Step twenty-six: Evaluating education training effects and changes - observer Graph 2 (Momirović et al., 1987; Bonacin, 2004; Milošević \& Milošević, 2013; Milošević \& Milošević, 2014; Milošević et al., 2014a; Milošević et al., 2014b; Milošević et al., 2014c; Nemec et al., 2016; Milošević et al., 2016).

Step twenty-seven: An education training programme which is programmed in the aforementioned manner is the basic input variable $(\mathrm{U})$ in the managing model, Graph 1 (Momirović et al., 1987; Bonacin, 2004; Milošević \& Milošević, 2013; Milošević \& Milošević, 2014; Milošević et al., 2014a; Milošević et al., 2014b; Milošević et al., 2014c; Nemec et al., 2016; Milošević et al., 2016).

Step twenty-eight: Generating and providing data input of the most effective training programmes for the basic and advanced sports education, and particularly education for managing fights and competitions for aerobic, alactate and lactate training sessions, as training sessions in speed and force, as well as programming current and cumulative education, mechanic, myogenic, neurogenic, biochemical and physiological effects and changes, that is, advancement which generates programmed training for one or more training sessions of a certain age, team, group or an individual athlete during a training period of one week, month or year - model output, Graph 1 (Momirović et al., 1987; Bonacin, 2004; Milošević \& Milošević, 2014).

\section{The model for managing education training effects and changes}

Athletes' performance is evaluated through the effects, quantitative and qualitative changes, and specific skills and processes which influence the quality and speed realisation of their movements. The desired effects are generated by applying education training effects (operators) in accordance with the set goals (Tomić \& Nemec, 2012; Milošević \& Milošević, 2014; Milošević et al., 2014a; Milošević et al., 2014b; Milošević et al., 2014c; Nemec et al., 2016; Milošević et al., 2016). The state model is used as the basis (Milošević \& Milošević 2014) for rational managing of effects and changes. Consequently, the state of the system presents the smallest set of factors which at a particular time frame enables (Momirović et al., 1987; Bonacin, 2004; Milošević \& Milošević 2014) the following:

- A thorough explanation of athletes' functioning and characteristics as a biological system (the manner of functioning, adaptive characteristics, regulation mechanisms, information and energy processes, relations, effects, and changes);

- Predicting an athlete's behaviour;

- Simulation in order to determine optimal changes in athletes' adaptive characteristics, processes and specific skills according to the requirements of sports fields and applied programmes.

An individual or group transitions from one state (initial) to the other (transitive or final) projected state, herein. Therefore, the state of an individual athlete or group is presented via state variables, whereas the set of all state variables shows the state space, while the motion through trajectories of state space is defined as system behaviour (of an 
individual athlete or a group) in the given space (Milošević \& Milošević, 2014). The state of the system is shown via motor variables (muscle contraction and bioenergetics potential, specific motor skills) since they are the prominent parts of every motion. Other variables such as psychological and morphological, variables showing energy and tactical requirements of combats-competitions, and others influence the quality and speed of specific movement in sports, directly or serve as a reducer or intensifier of motor variable' influences. Thus, it is rather necessary to be familiar with their relation to motor variables for the purpose of improving management (Milošević \& Milošević, 2014). With such a predefined state model, the general model of managing input (space for input variables $\mathrm{U}$ ), state space $(\mathrm{X})$, and output (space for output variables $\mathrm{Y}$ ) are shown in Graph 1 where operators (blocks) depict the following transformations:

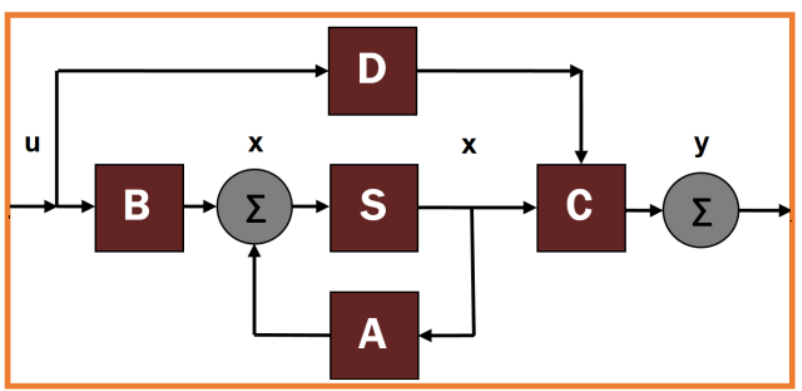

Graph 1 State model (Milošević \& Milošević, 2014)
$\mathrm{A}: \mathrm{X} \rightarrow$
$\mathrm{X}_{\mathrm{n}+1}-$ system matrix,
$\mathrm{B}: \mathrm{U} \rightarrow$
$\mathrm{X}$ - input matrix,
$\mathrm{C}: \mathrm{X} \rightarrow \mathrm{Y}$ - output matrix,
$\mathrm{D}: \mathrm{U} \quad \rightarrow \quad \mathrm{Y}$ - direct input-output relation matrix, while S shows current response operator of an athlete's organism between two transitional states.

Matrix A shows training operators (programmes), that is, the matrix of training system functioning. It consists of the coefficient presenting the relation between training which is depicted via models, methods, scope and intensity, distribution of training and education stimuli, other environmental factors together with effects and changes which are generated by the scope of the state of the system. Matrix B is the managing matrix (control operator), that is, the matrix of input variable (U) decomposition. Matrix $\mathrm{C}$ is the mechanism of system's functional composition of decomposed space state $(\mathrm{X})$. Matrix D shows the relation between the criteria of system management in the managing space. System performance is presented in its mathematical form by the following equations:

$$
\mathrm{X}_{\mathrm{n}+1}=\mathrm{Ax}_{\mathrm{n}}+\mathrm{Bu}, \mathrm{Y}_{\mathrm{n}}=\mathrm{Cx}_{\mathrm{n}}+\mathrm{Du}, \mathrm{x}\left(\mathrm{t}_{0}\right)=\mathrm{x}_{0}
$$

The data that follows provide the information on the main issue while programming and managing the management model. It provides adequate support in the form of gathering greater amount of precise output data at the right time (current and cumulative effects and changes generated by applying education training programmes) which describes the system 
(by using sub-systems of binary relations according to the state or system output). The issue of state recording is resolved through observer constitution (Graph 2), that is the mechanism for evaluating or measuring relevant state variables and output of the given system (Milošević \& Milošević, 2014). Such an expanded model manages the observer, operators of the reference input value $(\mathrm{F})$ and feedback $(\mathrm{K})$, as the space of evaluated states $(\mathrm{X})$ and reference stimulus (V) which is shown in Graph 2.

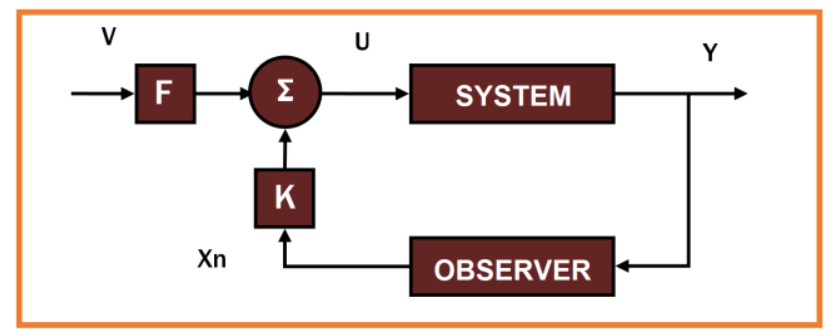

Graph 2 Observer (Milošević \& Milošević, 2014) $\Sigma$

As opposed to the system matrix A representing natural auto regulation system behaviour as shown in Graph 1, the observer is identified as a mechanism for observing variables of the manifested state in extended form, which in combination with the reference operator input $\mathrm{F}$ and imposed feedback (regulator $\mathrm{K}$ ) portrays a forced managing system of athletes' states.

The aforementioned managing concept provides more thorough dealing with this issue which implies, accepts and incorporates wider social interest, financial limitations and other non-specific factors.

The extended system showing an estimated athlete's state is presented in the form of the following differential equation:

$$
\mathrm{x}_{\mathrm{n}+1}=\mathrm{A}_{0} \mathrm{x}_{\mathrm{n}}+\mathrm{B}_{0} \mathrm{Y}_{0}+\mathrm{Bu},
$$

$\mathrm{A}_{0}, \mathrm{~B}_{0}$ shows the observer's specific characteristics presented mathematically.

\section{Information technology support for the model of managing education training effects and changes}

Due to the fact that the suggested methodology requires complex operations consisting of a greater number of variables, and applying relatively complex mathematical and statistical procedures, it is necessary to provide information technology support by programming a hardware and software system with automatic data gathering and processing (Milošević \& Milošević, 2014). The main goal of this system is to gather all the data and information needed for planning, programming and managing training processes, observing and predicting athletes' states in the scope of their skills and performance technique. System specific goals include (Momirović et al., 1987; Bonacin, 2004; Milošević \& Milošević, 2014):

- Determining and observing specific skills based on the number of selected and organised pieces of information which are comprehensible and applicable to the experts in the field; 
- Providing adequate information needed for programming, managing and predicting the effects of sporting advancement through automatic data gathering, and data compiled through measuring and testing;

- Profiling the data on individual athlete's states based on gathered and relevant information;

- Programming various education training programmes and managing generated effects and changes;

- Providing relevant information to experts and trainers as the basis for strategic planning and evaluation of expert work in the field;

- Performing rational and detailed selection of potential sports staff based on the collected data.

In order to meet the demands, it is essential to form the following four subsystems: 1) the Motor skills subsystem; 2) Specific skills subsystem; 3) Information on data and training effect programmes subsystem; 4) The subsystem for programming education training programmes (Patsiaouras, Moustakidis, Charitonidis, \& Kokaridas, 2011; Veličković, Petković, \& Petković, 2013; Milošević \& Milošević, 2014; Milošević et al., 2018).

Apart from the aforementioned subsystems two additional subsystems, as an integral part of the system, are needed in order to collect data on morphological and psychological status (Milošević \& Milošević, 2014). A database for every mentioned subsystem is created while the usage of various mathematical and statistical operations is used as an integral part of the subsystem for programming training programmes. It is easy to manage training effects and changes by performing those operations for the analysis of certain education training programmes on an athlete's change of state. As the effect of the completed analysis of the subsystem generates programming, such training programmes are entirely adjusted to meeting the set goals and tasks in a particular sports field or training session.

Consequently, the purpose of the system is acquiring, input and data analysis, programming and managing education training programmes. Technical support for programming and managing methodology for education training programmes are software programmes for force acquisition, electromyography, timing, photocells, contact platforms, sensors, the equipment needed for competitions and combats analysis, modules for data input, calculating coefficient of exponential equations, for calculating spline method coefficient equation, for graphing equations, client report, reports, writing and report analysis and peripheral equipment such as biomechanical measuring systems, force platform, video system, probes, dynamometer, functional capacity evaluation equipment, cardiovascular endurance, biochemical testing, postural status and anthropometric testing (Veličković et al., 2016).

\section{Methods for developing algorithm and performing analysis for education training effects and changes}

In certain steps for programming education training programmes a model of similarities and differences is used, like a residue, linear stochastic model, component, taxonomy, canonical and regression model (Momirović et al., 1987; Milošević \& Milošević, 2014).

Defining current and cumulative training effects (goals) of an individual athlete for one or more training sessions is performed in accordance with the diagnosed initial state or transition state and energy requirements of competitions by applying polynomial 
trending (Momirović et al., 1987; Bonacin, 2004; Milošević \& Milošević, 2014; Nemec et al., 2016).

Calculating performance capacity variables of an athlete and programming the quantity of force production, the speed of performance, the duration of performance, the spatial perimeter of performance, the amount and frequency of performed training, the frequency and duration of intermissions, etc., which generate programmed current or cumulative effects and changes for one or more training sessions, are performed by using a non-linear multiple regression method (Momirović et al., 1987; Bonacin, 2004; Milošević \& Milošević, 2014; Nemec et al., 2016).

The analysis and evaluation of technical, tactical, aerobic, alactate and lactate training and force training, its current and cumulative mechanic, myogenic, neurogenic, biochemical and physiological effects of teams, national teams, or an entire sports field require canonical and regression methods with or without separating previous transitive states (Momirović et al., 1987; Bonacin, 2004; Milošević \& Milošević, 2014).

The analysis of practical and theoretical training effects on the structure of groups, teams, and national teams work with different factor models and methods. Comparing the energy state of one training session to the energy state of one fight or any other first-rate competition is performed by applying non-linear factor solutions. The efficiency of the education training process is determined through the degree of similarity (Mahalanobis distance) of education training effects of one training session and energy force requirements of one fight or any other international competition (discriminant analysis). Comparative analysis, evaluation of various education training programmes and the selection of the best among them is performed by applying taxonomy and factor methods. Determining metric characteristics of observed variables, athlete's classification, and normative evaluation of education training effects is performed by conducting factor and robust discriminant analysis (Momirović et al., 1987; Bonacin, 2004; Milošević \& Milošević, 2014; Brezić, 2016).

Defining voluntary influence (field, the manner of influence, the type of influence, the regimen of influence, the intensity of influence) of training models and methods at the set time is completed through applying canonical and non-linear multiple analysis (Momirović et al., 1987; Bonacin, 2004; Milošević \& Milošević, 2014).

Defining the final number of training models and methods is completed through nonlinear factor analysis solutions (Momirović et al., 1987; Milošević \& Milošević, 2014).

The analysis of quantitative education training changes (technical, tactical, mechanic, myogenic, neurogenic, energy, biochemical and physiological) of teams, national teams, or the entire sports field is completed through applying: differences model, similarities model, residue model, linear stochastic model and canonical model (Momirović et al., 1987; Bonacin, 2004; Milošević \& Milošević, 2014).

The analysis of qualitative education training changes is conducted by applying a component model, taxonomy model, canonical model and the analysis of regression parameters (Momirović et al., 1987; Milošević \& Milošević, 2014).

The generated changes are analysed by applying spectral analysis of state changes of one method (technical tactical skills, aerobic, anaerobic, force, etc.), spectral analysis of the curve of change of one variable registered on more subjects and at various points in time, the analysis of absolute and relative individual changes and the analysis of polynomial trending changes of an individual athlete, team, national team or the entire sports field (Momirović et al., 1987; Bonacin, 2004; Milošević \& Milošević, 2014). 
Calculating the function of training changes of an individual, team or a national team at a certain time, determining metric characteristics of observed variables and forming a normative for training changes evaluation (advancement) is completed by conducting taxonomy and non-linear regression analysis (Momirović et al., 1987; Bonacin, 2004; Milošević \& Milošević, 2014).

\section{CONCLUSION}

The findings have theoretical implications for methodological steps, programming algorithms, models and methods implemented in the process of programming and managing education training programmes and give an insight into the calculating, analysis, control and managing of education training effects and changes. In accordance with the aim of the paper the multidimensionality of programming and managing methodology are highlighted. The presented methodological approach in designing education and training can be applied to all sports, however, not in its entirety, due to the specific methodological steps of some sports.

\section{REFERENCES}

Bonacin, D. (2012). Uvod u kvantitativne metode (Introduction to quantitative methods). Kaštela: Self edition of author. In Croatian

Brezić, G.S. (2016). Diskriminacioni kriterijumi uspešnosti u odbojkaškoj igri (Discriminatory criteria of success in volleyball). PhD Thesis. Belgrade: Faculty of Sport and Physical Education, University of Belgrade. In Serbian

Momirović, K., Prot, F., Dugić, D., Knezović, Z., Bosnar, K., Erjavec, N., et al. (1987). Metode, algoritmi $i$ programi za analizu kvantitativnih i kvalitativnih promena (Methods, algorithms and programs for analysis of quantitative and qualitative changes). Zagreb: Institute of Kinesiology, Faculty of Physical Culture, University of Zagreb. In Croatian

Milošević, M.M., Mudrić, M., Mudrić, R., \& Milošević, B.M. (2012). Using the mind in reprogramming the limits of muscle force in the process of creating champions. Sport Science \& Practice, 2(5), 39-58.

Milošević, B.M., \& Milošević, M.M. (2013). Model for assessing the physical status, as well as prediction and programming of training and sports performance of a soccer player. Journal of Physical Education and Sport, 13(4), 479-488

Milošević, B.M., Nemec, M.P., Životić, R.D., Milošević, M.M., \& Rajović, D.R. (2014a). Force distribution model of motor units of leg extensor muscles. Journal of Sports Science, 2(3), 195-199.

Milošević, B.M., Milošević, M.M., Nemec, MP., Životić, R.D., \& Rađo, I.I. (2014b). A new approach to development of human maximal muscular force. Journal of Exercise Physiology Online, 17(5), 70-80.

Milošević, B.M., Džoljić, E., Milošević, M.M., \& Yourkesh, M., \& Behm, G.D. (2014c). The analysis of muscle force development with trained and elite athletes. Physiology, 24(1-81), 5-12.

Milošević, B.M. \& Milošević, M.M. (2014). Special physical education: Textbook on the management of the construction of the physical integrity and capacity of police officers. Saarbrücken, Germany: LAP Lambert Academic Publishing.

Nemec, P., Milošević, M.M., Nemec, V. \& Milošević, B.M. (2016). Production and development of muscle force in elite male volleyball players' spike. Sport Science, 9(2), 32-40.

Milošević, B.M., Nemec, V., Jourkesh, M., Nemec, P., Milošević, M.M., \& Behm, D. (2016). Detrrmination of capacity and rules of the variability of maximum force using nonlinear athematical models: A case study. Central European Journal of Sport Sciences and Medicine, 16(4), 91-101.

Milošević, M. B., Nemec, V., Nemec, P., Milošević, M. M. (2017). Programming methodology and control of aerobic training by running. Acta Kinesiologica, 11( 1), 53-57.

Milošević, B.M., Nemec, P., Nemec, V., Milošević, M.M. (2018). The impact of a 4-week aerobic training program on the aerobic status of top-level judokas. Facta Universitatis Series Physical Education and Sport, 16(1), 201-210 
Patsiaouras, A., Moustakidis, A., Charitonidis, K., \& Kokaridas, D. (2011). Technical skills leading in winning or losing volleyball matches during Beijing Olympic Games. Journal of Physical Education and Sport, 11(2), 39-42.

Tomić, D., \& Nemec, P. (2012). Odbojka u teoriji i praksi (Volleyball in theory and practice). Belgrade: Self edition of authors.

Veličković, S., Bubanj, S., Stanković, R., Popović, R., Herodek, K., Živković, D., et al. (2016). A study on anthropological status and biomechanical efficiency of the elite Serbian athletes. In S. Bubanj (Ed.). Faculty of Sport and Physical Education, University of Niš.

Veličković, S., Petković, D. \& Petković, E. (2013). The effects of programmed physical preparation on the transformation of motor skills of young soldiers of various specialties. Military Operations Research, 18(2), 49-59.

\section{METODOLOGIJA PROGRAMIRANJA I UPRAVLJANJA OBRAZOVNIH TRENAŽNIH PROGRAMA}

Osnovni cilj ovog rada bio je da se predstavi teorijsko znanje $i$ da se odgovori na pitanje organizacije, programiranja, vođenja i upravljanja trenažnim procesom u cilju postizanja najboljih mogućih obrazovnih efekata treninga i generisanja planiranih promena $u$ domenu pruženih znanja, sposobnosti $i$ veštine ljudi uključenih u sport. Nalazi imaju teorijske implikacije na metodološke korake, algoritam programiranja, modele i metode primenjene u procesu programiranja $i$ upravljanja programima obrazovanja $i$ daju uvid u izračunavanje, analizu, kontrolu $i$ upravljanje efektima treninga $i$ promenama. $U$ skladu sa ciljem rada, istaknuta je višedimenzionalnost programa $i$ upravljačkih kapaciteta. Predstavljeni metodološki pristup u dizajniranju obrazovanja i treninga može se primeniti na sve sportove, ali ne u celosti, zbog specifičnih metodoloških koraka nekih sportova.

Ključne reči: algoritam, metodologija programiranja, efekti treninga, trenažne promene. 